\title{
IIIIIIIIIITा \\ Chitosan gels for buccal delivery of Schinus molle $L$. essential oil in dogs: characterization and antimicrobial activity in vitro
}

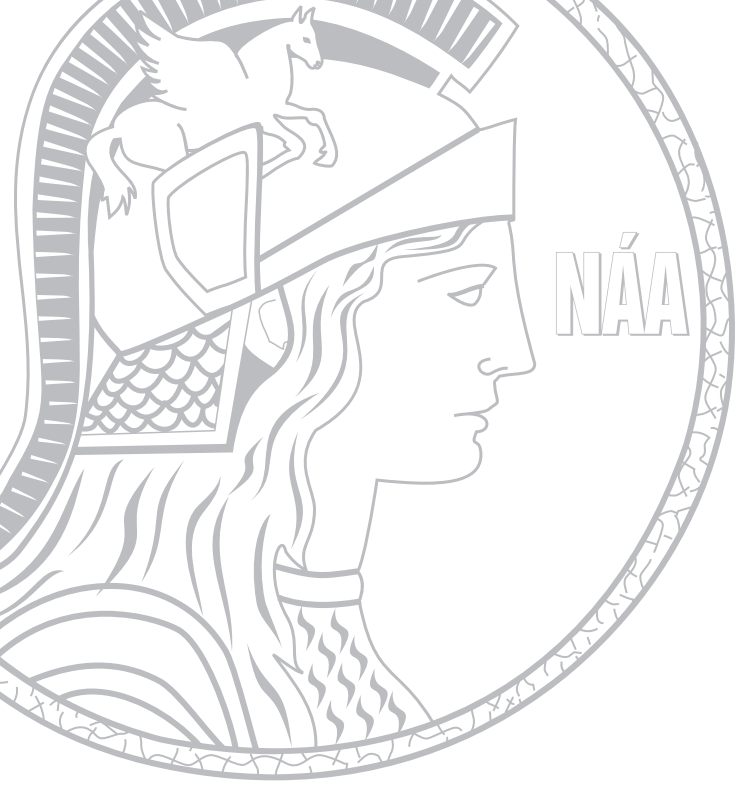

\author{
MELINA C.C. ALVES, DOUGLAS S.A. CHAVES, BYANCA R. BENEVENUTO, \\ BEATRIZ O. DE FARIAS, SHANA M.O. COELHO, THAIS P. FERREIRA, \\ GERALDO A. PEREIRA, GABRIELA C.M. DOS SANTOS, LEANDRA O. MOREIRA, \\ JULIANA P. FREITAS \& YARA P. CID
}

\begin{abstract}
Periodontal disease is considered the main oral cavity disorder in dogs. Essential oils have the potential for use in the prevention and treatment of oral diseases. The antimicrobial activity of Schinus molle L. essential oil (SMEO) has already been reported. Chitosan, a natural product with antimicrobial activity and good biocompatibility has potential in biodental applications. In this study, we evaluated the in vitro antimicrobial activity of SMEO against bacteria associated with periodontal disease in dogs, developed and evaluated the physicochemical properties of a novel chitosan-based buccal delivery system containing SMEO. SMEO showed antimicrobial activity against Gram positive and Gram negative bacteria associated with canine periodontitis, with MIC values of $750 \mu \mathrm{g} \cdot \mathrm{mL}^{-1}$ for Staphylococcus spp. and Streptococcus spp, $1000 \mu \mathrm{g} \cdot \mathrm{mL}^{-1}$ for Corynebacterium spp. and $1250 \mu \mathrm{g} \cdot \mathrm{mL}^{-1}$ for Pseudomonas spp. All formulations evaluated presented adequate physicochemical properties, good stability, and $\mathrm{pH}$ values close to buccal pH (5.0-7.0). Chitosan gel loaded with SMEO showed potential as a SMEO delivery system, having the ideal physicochemical and rheological properties (pseudoplastic and apparent viscosities) required for application on buccal tissue. Thus, we can conclude that formulation has the potential to be used for buccal mucosa delivery in the prevention and treatment of periodontal disease in dogs.
\end{abstract}

Key words: essential oils, gel mucoadhesive, periodontitis canine, Schinus molle L.

\section{INTRODUCTION}

Periodontal disease is an oral disease caused by the agglomeration of biofilms composed of bacteria and their products on the surface of the teeth and gums, which promote the progressive inflammatory process of the periodontium (Perchyonok 2018). It commonly occurs in dogs, being their main oral cavity disease (Kačírová et al. 2019).

Plant extracts, essential oils and purified phytochemicals have the potential for use in the prevention and treatment of oral diseases (Palombo 2011). The antimicrobial activity against oral pathogens in humans of some essential oils, such as Melaleuca alternifolia (Hammer et al. 2003), Artemisia lavandulaefolia and Artemisia scoparia (Cha et al. 2005), Lavandula officinalis (Takarada et al. 2004), Lippia sidoides (Botelho 2007), and Ocimum basilicum (Besra \& Kumar 2018), have already been reported. Several essential oils, such as Thymus vulgaris, Rosmarinus officinalis L., Origanum vulgare, Syzygium aromaticum, have been used as nutraceuticals in the treatment and prevention of canine periodontitis (Gupta et al. 2019). 
Essential oils (EOS) from Schinus molle L. (Anacardiaceae) has shown antioxidant (Martins et al. 2014), ectoparasiticidal (Batista et al. 2016) and antihemostatic properties (Siqueira et al. 2020). Their antimicrobial activity has also been reported (Marino et al. 2001, Deveci et al. 2010, Martins et al. 2014, Eryigit et al. 2017).

The development of buccal delivery systems for treating periodontitis is necessary to obtain prolonged local effect in the oral cavity. Due to its antimicrobial activity and biocompatibility, chitosan (CHT) is a potential material for biodental applications (Husain et al. 2017). Furthermore, its adhesion properties (Brannigan \& Khutoryanskiy 2019) make chitosan-based formulations, such as films or gels, suitable for delivery systems in the prevention and treatment of periodontal disease (Gupta et al. 2019).

We evaluated the in vitro antimicrobial activity of Schinus molle L. essential oil (SMEO) against bacteria associated with periodontal disease in dogs. Moreover, we developed a novel chitosan-based buccal delivery system containing SMEO and evaluated the influence of both dimethyl sulfoxide (DMSO) and EO concentrations on gels' properties ( $\mathrm{pH}$, rheology, physical stability) to gauge the potential of these formulations as buccal delivery systems for the treatment and prophylaxis of canine periodontal disease.

\section{MATERIALS AND METHODS}

\section{Plant material}

Leaves of S. molle were collected during the summer of 2017 in the city of Volta Redonda, Rio de Janeiro, Brazil (GPS 22 31'36.23S; $4^{\circ} 04^{\prime} 31 \cdot 62 \mathrm{~W}$ ). A voucher specimen was deposited with the herbarium of the Institute of Botany (UFRRJ, Brazil) under the code RBR 35791. Authorization to collect botanical material was obtained from the National Genetic Heritage and Associated
Traditional Knowledge Management System (A85E6DF).

\section{Extraction, content (\% w/w) and chemical characterization of the essential oil}

S. molle leaves were dried at room temperature, protected from light and moisture. Subsequently they were manually ground, subjected to the extraction process by hydrodistillation (50 g of dry leaves) and characterized by GC-FID and GC-MS as described by Cavalcanti et al. (2015) and Batista et al. (2016). To separate, detect and quantify the constituents, $1 \mu \mathrm{L}$ of the essential oil $(10 \mu \mathrm{L} / \mathrm{mL})$ was injected into the gas chromatograph (GC). A Hewlett-Packard 5890 Series II (Palo Alto, USA), equipped with flame ionization detection and a split/splitless injector, in a split ratio of 1:20 was used to separate and detect the constituents in the essential oil. The compounds were separated on a non-polar fused silica capillary column, similar to DB5 with $30 \mathrm{~m} \times 0.25 \mathrm{~mm}$ (i.d.) $\times 0.25 \mu \mathrm{m}$ (film thickness) Helium was used as the carrier gas at a flow rate of $1.0 \mathrm{~mL} / \mathrm{min}$. The column temperature was programmed as follows: $60^{\circ} \mathrm{C}$ for 2 min followed by heating at $5^{\circ} \mathrm{C}$ min- 1 to $110^{\circ} \mathrm{C}$, followed by heating at $3^{\circ} \mathrm{C}$ min-1 to $150^{\circ} \mathrm{C}$ and finally by heating at $15^{\circ} \mathrm{C}$ min- 1 until $290^{\circ} \mathrm{C}$ and holding constant for $15 \mathrm{~min}$. The injector temperature was $220^{\circ} \mathrm{C}$ and the detector temperature was $290^{\circ} \mathrm{C}$. For GC/MS analysis, $1 \mu \mathrm{L}$ of essential oil was injected in the gas chromatograph coupled to mass spectrometer (GC-MS) QP-2010 Plus (Shimadzu, Japan). The flow of the helium gas carrier, the capillary column and the temperature conditions for the GC-MS analysis were the same as described for the GC. The temperature of the injector was $220^{\circ} \mathrm{C}$ and the temperature of the interface was $250^{\circ} \mathrm{C}$. Mass spectra were obtained with a quadrupole detector operating at $70 \mathrm{eV}$, with $40-400 \mathrm{~m} / \mathrm{z}$ mass range and scanning rate equal to 0.5 scan s$^{-1}$. 


\section{Minimum inhibitory concentration (MIC)}

The minimum inhibitory concentration was determined by the broth microdilution technique in the concentration range of $0.625-20,000$ $\mu \mathrm{g} \cdot \mathrm{mL}^{-1}$ in DMSO. The analyses were carried out in triplicate. The oral bacterial strains used in this study were Corynebacterium spp, Pseudomonas spp, Staphylococcus aureus and Streptococcus. spp, isolated from animal samples belonging to the bacterial stock of the Veterinary Bacteriology Laboratory-UFRRJ, according to CLSI (2018).

\section{Preparation of gels}

Chitosan (degree of deacetylation of $76 \%$ ) was purchased from sigma-Aldrich and gels were prepared based on previous studies (Cid et al. 2012). Pure CHT gels (chitosan gels without active ingredients or adjuvants) were obtained by dispersion of appropriate amounts of $\mathrm{CHT}$ in $1 \%$ aqueous lactic acid (stirred mechanically until homogenization), yielding 3.0\% (w/w) of gels. Gels were loaded with weighed amounts of DMSO, the penetration enhancer (1.0\%, 2.0\%, and $3.0 \% \mathrm{w} / \mathrm{w}$ ), and SMEO to final concentrations of $0.125 \%, 0.25 \%$ and $0.5 \%(\mathrm{w} / \mathrm{w})$. Concentrations of CHT, SMEO and DMSO reported in Table I are expressed as weight/weight percentages (\% $w / w)$. No insoluble particles were observed after preparation of the gels.

\section{Evaluation of gel formulations}

\section{Physical appearance of gel formulations}

The gels were subjected to visual analysis for opacity, consistency and presence of particles.

\section{Determination of $\mathrm{pH}$ of gel formulations}

The $\mathrm{pH}$ values were determined with a potentiometer fitted with a DME-CV4 electrode. One gram of each formulation was weighed and homogenized in $10.0 \mathrm{ml}$ of purified water in a glass container. Measurements were performed in triplicate and means and standard deviations were calculated.

\section{Centrifugation test}

The centrifugation test was performed under refrigeration, where 1.0 gram of each formulation was transferred to an Eppendorf tube and centrifuged at 3,000 rpm for 30 minutes and at $3800 \mathrm{rpm}$ for 5 hours, each formulation was checked in terms of sedimentation (Aslani et al. 2018).

\section{Cooling and heating test}

In order to evaluate the thermal stability, the formulations were submitted to freezing and thawing cycles. In this case, 1.0 gram of each formulation was transferred to an Eppendorf tube and subjected to three 48-hour cycles at $45^{\circ} \mathrm{C}$ and $4^{\circ} \mathrm{C}$ (Aslani et al. 2018).

\section{Rheological measurements}

Oscillatory measurements were carried out at $25^{\circ} \mathrm{C}$ with a Thermo Scientific HAAKE RheoStress 1 rotary rheometer with cone-plate geometry and \#CP52 spindle. Samples were placed in the cylinder and the internal rotating spindle was set to rotate at rising angular velocity ( $1 \mathrm{rpm}$ to $20 \mathrm{rpm}$ ), to initially disrupt the system, which was then reorganized by decreasing the angular velocity. All measurements were performed at room temperature. CHT gels containing SMEO and DMSO in different concentrations were evaluated using the power law rheological model to determine the effects of flow index, consistency index and viscosity (apparent viscosity). 
Table I. Rheological parameters and $\mathrm{pH}$ values in formulations containing chitosan gel $3 \%$ and different concentrations of Schinus molle essential oil and dimethyl sulphoxide.

\begin{tabular}{|c|c|c|c|c|c|}
\hline & Formulation & Flow index (n) & $\begin{array}{c}\text { Consistency } \\
\text { index }\end{array}$ & $\begin{array}{c}\text { Apparent } \\
\text { viscosity (mPA) }\end{array}$ & pH value* \\
\hline 1 & CHT pure gel $3 \%$ & 0.4033 & 276.6 & 4282 & $5.01 \pm 0.03^{\mathrm{a}}$ \\
\hline 2 & CHT gel 3\% + DMSO 1\% & 0.4093 & 249.5 & 3893 & $5.02 \pm 0.01^{\mathrm{a}}$ \\
\hline 3 & CHT gel $3 \%+$ DMSO $2 \%$ & 0.4118 & 263.6 & 4185 & $5.00 \pm 0.04^{\mathrm{a}}$ \\
\hline 4 & CHT gel $3 \%+$ DMSO 3\% & 0.4201 & 272.0 & 4889 & $5.00 \pm 0.05^{\mathrm{a}}$ \\
\hline 5 & CHT gel 3\% + SMEO 0.125\% & 0.4755 & 376.2 & 7233 & $5.01 \pm 0.03^{a}$ \\
\hline 6 & $\begin{array}{c}\text { CHT gel 3\% + SMEO } 0.125 \%+ \\
\text { DMSO } 1 \%\end{array}$ & 0.5083 & 314.3 & 6667 & $5.01 \pm 0.04^{\mathrm{a}}$ \\
\hline 7 & $\begin{array}{c}\text { CHT gel } 3 \%+\text { SMEO } 0.125 \%+ \\
\text { DMSO } 2 \%\end{array}$ & 0.5186 & 318.9 & 6983 & $5.05 \pm 0.03^{\mathrm{a}}$ \\
\hline 8 & $\begin{array}{c}\text { CHT gel 3\% + SMEO } 0.125 \%+ \\
\text { DMSO 3\% }\end{array}$ & 0.4946 & 379.6 & 7724 & $5.08 \pm 0.02^{a}$ \\
\hline 9 & CHT gel 3\% + SMEO 0.250\% & 0.4338 & 464.5 & 7848 & $5.12 \pm 0.01^{b}$ \\
\hline 10 & $\begin{array}{c}\text { CHT gel 3\% + SMEO } 0.250 \%+ \\
\text { DMSO } 1 \%\end{array}$ & 0.4580 & 412.3 & 7414 & $5.13 \pm 0.01^{b}$ \\
\hline 11 & $\begin{array}{c}\text { CHT gel } 3 \%+\text { SMEO } 0.250 \%+ \\
\text { DMSO } 2 \%\end{array}$ & 0.3977 & 649.0 & 9799 & $5.12 \pm 0.01^{b}$ \\
\hline 12 & $\begin{array}{c}\text { CHT gel } 3 \%+\text { SMEO } 0.250 \%+ \\
\text { DMSO 3\% }\end{array}$ & 0.4509 & 427.3 & 7636 & $5.14 \pm 0.01^{b}$ \\
\hline 13 & CHT gel 3\% + SMEO 0.500\% & 0.4337 & 253.5 & 4286 & $5.17 \pm 0.01^{c}$ \\
\hline 14 & $\begin{array}{c}\text { CHT gel 3\% + SMEO } 0.500 \%+ \\
\text { DMSO } 1 \%\end{array}$ & 0.4308 & 267.6 & 4479 & $5.18 \pm 0.02^{c}$ \\
\hline 15 & $\begin{array}{c}\text { CHT gel } 3 \%+\text { SMEO } 0.500 \%+ \\
\text { DMSO } 2 \%\end{array}$ & 0.3870 & 323.3 & 4766 & $5.23 \pm 0.02^{d}$ \\
\hline 16 & $\begin{array}{c}\text { CHT gel 3\% + SMEO } 0.500 \%+ \\
\text { DMSO 3\% }\end{array}$ & 0.3986 & 309.2 & 4722 & $5.27 \pm 0.01^{e}$ \\
\hline
\end{tabular}

CHT: chitosan, SMEO: Schinus molle essential oil, DMSO: dimethyl sulphoxide.

${ }^{*} \mathrm{pH}$ values \pm sd.

Different letters differ significantly $P<0,05$.

Equal letters do not differ significantly from each other $P>0,05$. 


\section{RESULTS}

\section{Chemical composition of Schinus molle}

Our research group has previously published a number of papers on S. molle extracts and analysis of its essential oil. These papers have shown SMEO to be rich in monoterpenes (1 $\beta$-pinene - 6.7\%; 2 - trans-pinocarveol - 6.2\%) and sesquiterpenes (3 - spathulenol - 11.7\%, 4 - cubenol - $127.1 \%$ and 5 - caryophyllene oxide 15.3\%) (Batista et al. 2016, Cavalcanti et al. 2015, Siqueira et al. 2020). These are reported in Figure 1.

\section{Minimum inhibitory concentration (MIC) determination}

The broth microdilution technique revealed that Staphylococcus spp. and Streptococcus spp. presented the lowest MIC value $\left(750 \mu \mathrm{g} \cdot \mathrm{mL}^{-1}\right)$, followed by Corynebacterium spp., which presented $1000 \mu \mathrm{g} \cdot \mathrm{mL}^{-1}$, and Pseudomonas spp., with the highest value, $1250 \mu \mathrm{g} \cdot \mathrm{mL}^{-1}$.

\section{Evaluation of gel formulations}

The formulations submitted to centrifugal and thermal tests showed good stability, with no phase separation under the experimental conditions tested.

The organoleptic characteristics were influenced by the addition of DMSO and SMEO. Formulations \#1 to \#4 showed yellowish color and opacity, with characteristic chitosan odor and taste. The incorporation of the SMEO in different concentrations (\#5 to \#16) altered the odor, which became that characteristic of the essential oil of S. molle. In addition, formulations with a higher concentration of essential oil (0.5\%) showed increased opacity and consistency. No precipitation or dispersed particles were observed in the gel, demonstrating the compatibility of the formulation components.

The formulations showed $\mathrm{pH}$ values around 5.0, close to buccal pH (5.0-7.0) (Mangilal et al. 2019), thus suitable for buccal application (Table I).

The incorporation of DMSO (penetration enhancer) at different concentrations did not influence the $\mathrm{pH}$ values, since there was no statistical difference between loaded gels (\#2, \#3, \#4) and pure gel (\#1) (Table I). The incorporation of SMEO at the lowest concentration (\#5) did not influence the $\mathrm{pH}$ either, but the increase of EO concentration led to an increase of $\mathrm{pH}$ values (\#9, \#13).

The gel loaded with DMSO at the highest concentration (\#4, $4889 \mathrm{mPa}$ ) had higher apparent viscosity than the pure gel (\#1, $4282 \mathrm{mPa}$ ). The addition of $\mathrm{OE}$ at the highest concentration (\#13) did not affect the apparent viscosity (4286 $\mathrm{mPa})$. However, at lower concentrations $(0.125 \%$ and $0.250 \%$ ), the apparent viscosity increased, reaching $7233 \mathrm{mPa}(\# 5)$ and $7848 \mathrm{mPa}(\# 9)$. Gel loaded with $0.250 \%$ SMEO had higher apparent viscosity with the addition of DMSO, reaching $9799 \mathrm{mPa}$ at a concentration of 2\% (\#11).

The rheograms showed concave curves for shear stress in relation to shear rate. An inversely

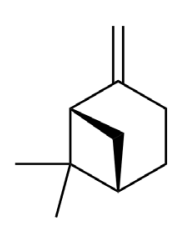

1

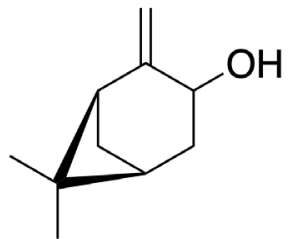

2

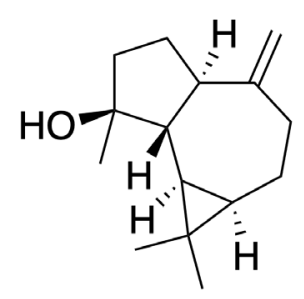

3

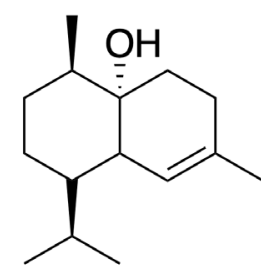

4

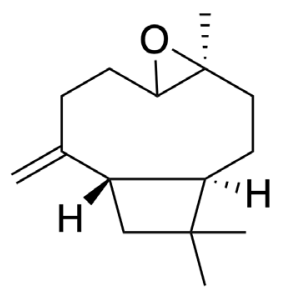

5

Figure 1. Chemical structures of the major compounds from Schinus molle essential oil. 
proportional relationship between these two parameters was observed (Figure 2). This curve profile is characteristic of non-Newtonian fluids and represents pseudoplastic behavior (Rapp 2017). This behavior was confirmed by the flow index (n) evaluation, where all formulations presented $n$ value less than 1 , the characteristic value of fluids classified as pseudoplastic (Table I) (Macossko et al. 1994). Decreasing apparent viscosity with increasing shear rate also characterizes pseudoplastic materials (Schott 1995).

\section{DISCUSSION}

Although the etiology of periodontal disease is poorly studied, it is known that bacteria play an important role (Williams et al. 2011). Among the organisms most often associated with this disease are Bacteroides fragilis, Porphyromonas salivosa, Prevotella intermedia (Gupta et al. 2019), P. gingivalis and P. intermedia (Ramseier et al. 2009), among others. Anaerobic Gram positive bacteria including Streptococcus spp. and Staphylococcus spp. are predominant at the beginning of plaque formation, while Gram negative bacteria become predominant with increased thickness and maturation of the biofilm (Gupta et al. 2019). Gram ${ }^{+}$(Streptococcus spp. and Staphylococcus spp.) and Gram (Corynebacterium spp. and Pseudomonas spp.) bacteria used in this study have already been associated with periodontitis in dogs (Pieri et al. 2014, 2016, Williams et al. 2011).

The results of our antibacterial activity assays showed that the SMEO exhibits greater antimicrobial activity against $\mathrm{Gram}^{+}$strains of Staphylococcus spp. and Streptococcus spp. (750 $\left.\mu \mathrm{g} \cdot \mathrm{mL}^{-1}\right)$ compared with the activity against Gram strains Corynebacterium spp. (1000 $\left.\mu \mathrm{g} \cdot \mathrm{mL}^{-1}\right)$ and Pseudomonas spp. (1250 $\left.\mu \mathrm{g} \cdot \mathrm{mL}^{-1}\right)$, corroborating the results reported by Martins et al. (2014). However, the values found in this study for Staphylococcus are higher than those reported by Martins et al. (2014) ( $\left.\mathrm{MIC}=125 \mu \mathrm{g} \cdot \mathrm{mL}^{-1}\right)$ and lower than those reported by Deveci et al. (2010) $\left(\mathrm{MIC}=2000 \mu \mathrm{g} \cdot \mathrm{mL}^{-1}\right)$. The different responses to antimicrobial activity can be explained by the diversity of the composition and concentration of each component in the SMEO (Marino et al. 2001). It is important to highlight the strong activity against Streptococcus spp., since they are described as the most important in the initial adhesion of dental plaque in humans (Katsura et al. 2001).

Some studies have already reported the activity of plant extracts, essential oils and purified phytochemicals against periodontitisrelated bacteria in dogs. Girão et al. (2003) reported significantly reduced histological and clinical aspects of the oral mucosa in treated with mouthwash of essential oil of Lippia menosides. Pieri et al. (2014) highlighted the potential of Copaifera officinalis oil for the treatment and prevention of canine periodontitis. The oil showed activity against Streptococcus spp. and Staphylococcus spp., but only at a high concentration (10\%). In another study, Pieri et al. (2016) demonstrated the activity of the compound $\beta$-caryophyllene as a natural alternative for the treatment and prophylaxis of periodontitis in dogs, but in much higher concentrations than in the present study, with MIC values in the range of 6.25 to $50 \mathrm{mg} \cdot \mathrm{mL}^{-1}$ against Streptococcus spp., and from 25 to 100 mg. $\mathrm{mL}^{-1}$ against Staphylococcus spp.

All formulations evaluated presented adequate physical properties and good stability when submitted to centrifugal and thermal tests, and $\mathrm{pH}$ values around 5.0, close to buccal pH (5.07.0) (Teelavath \& Patnaik 2019), meaning they are suitable for buccal application. The formulations also presented adequate rheological behavior, 

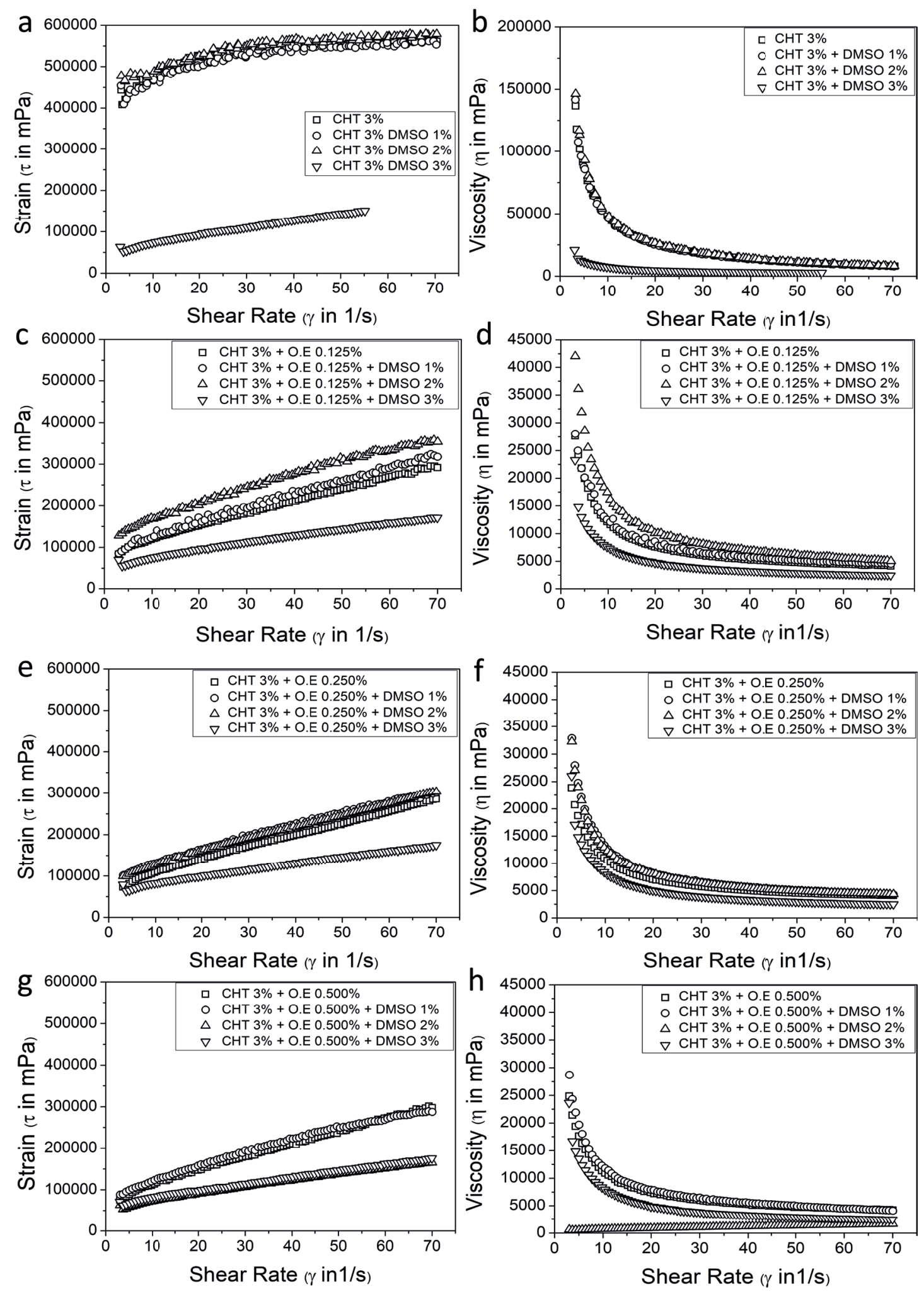

Figure 2. Stress curves and viscosity $(a, b)$ : formulations F1-F4 in the absence of Schinus molle essential oil; (c, d): formulations F5-F8 with Schinus molle essential oil 0.0125\%; $(\mathrm{e}, \mathrm{f})$ : formulations F9-F12 with Schinus molle essential oil $0.250 \%$; $(\mathrm{g}, \mathrm{h})$ : formulations F13-F16 with Schinus molle essential oil $0.500 \%$. 
presenting pseudoplastic properties with a flow index (n) less than 1 (Macossko et al. 1994, ElHefian \& Yahaya 2010). The flow index of pure chitosan gel (\#1) (0.4033) corroborates the value of 0.39 reported by Cid et al. (2012). In general, the pseudoplastic properties favor the local action of drugs, which remain longer in the free form, have increased bioavailability, and consequently have stronger local effect. This pseudoplastic behavior of chitosan hydrogels has already been reported in other studies (e.g. Perioli et al. 2008). Although all the formulations evaluated showed adequate physicohemical and rheological properties, the formulation containing $0.250 \%$ SMEO and 2\% DMSO (\#11) presented the highest values of apparent viscosity when compared to the other formulations. For buccal application, more viscous pharmaceutical forms have the advantage of a slow flow index, which minimizes the risks of poisoning by accidental swallowing, in addition to ensuring good adhesion and greater contact with the mucosa (Wróblewska et al. 2020).

SMEO showed antimicrobial activity against Gram positive and Gram negative bacteria associated with periodontitis in dogs. The 3\% chitosan gel loaded with $0.250 \%$ SMEO and $2.0 \%$ DMSO (\# 11) showed potential as a SMEO delivery system, having the ideal physicochemical and rheological properties $(\mathrm{pH}$, pseudoplastic and apparent viscosities) required for application on buccal tissue, so it has promise for administration of SMEO by buccal mucosa delivery for the prevention or treatment of periodontal disease in dogs. Our results are encouraging, however, additional in vitro and in vivo studies should be performed, such as the in vitro antimicrobial activity of the formulations, since chitosan is also antimicrobial and a possible synergistic effect can be observed, as well as in vivo assessments of efficacy and safety.

\section{Acknowledgments}

This study was financed in part by the Coordenação de Aperfeiçoamento de Pessoal de Nivel Superior Brasil (CAPES) - Finance Code 001. Conselho Nacional de Desenvolvimento Científico e Tecnológico (CNPq) and Fundação de Apoio à Pesquisa Tecnológica da Universidade Federal Rural Rio de Janeiro (FAPUR) also supported the study.

\section{REFERENCES}

ASLANI A, ZOLFAGHARI B \& FEREIDANI Y. 2018. Design, formulation, and evaluation of a herbal gel contains melissa, sumac, licorice, rosemary, and geranium for treatment of recurrent labial herpes infections. Dent Res J 15(3): 191-200.

BATISTA LCDS, CID YP, DE ALMEIDA AP, PRUDÊNCIO ER, RIGER C), DE SOUZA MA \& CHAVES DS. 2016. In vitro efficacy of essential oils and extracts of Schinus molle L. against Ctenocephalides felis felis. Parasitol 143(5): 627-638.

BESRA M \& KUMAR V. 2018. In vitro investigation of antimicrobial activities of ethnomedicinal plants against dental caries pathogens. 3 Biotech 8(257): 1-8.

BOTELHO MA, NOGUEIRA NAP, BASTOS GM, FONSECA SGC, LEMOS TLG, MATOS FJA, MONTENEGRO D, HEUKELBACH J, RAO VS \& BRITO GAC. 2007. Antimicrobial activity of the essential oil from Lippia sidoides, carvacrol and thymol against oral pathogens. Braz J Med Biol Res 40(3): 349-356.

BRANNIGAN RP \& KHUTORYANSKIY VV. 2019. Progress and Current Trends in the Synthesis of Novel Polymers with Enhanced Mucoadhesive Properties. Macromol Biosci 19(10): 190-194.

CAVALCANTI AS, ALVES MS, DA SILVA LCP, PATROCÍNIO DS, SANCHES MN, CHAVES DSA \& SOUZA MAA. 2015. Volatiles composition and extraction kinetics from Schinus terebinthifolius and Schinus molle leaves and fruit. Res Bras Farmacogn 25: 356-362.

CHA JD, JEONG MR, CHOI HJ, JEONG SI, MOON SE, YUN SI \& SONG YH. 2005. Chemical composition and antimicrobial activity of the essential oil of Artemisia lavandulaefolia. Plant Med 71(06): 575-577.

CID YP, PEDRAZZI V, DE SOUSA VP \& PIERRE MBR. 2012. In vitro characterization of chitosan gels for buccal delivery of celecoxib: influence of a penetration enhancer. AAPS Pharm Sci Tech 13(1): 101-111. 
DEVECI O, SUKAN A, TUZUN N \& KOCABAS EEH. 2010. Chemical composition, repellent and antimicrobial activity of Schinus molle L. J Med Plant Res 4(21): 2211-2216.

EL-HEFIAN EA \& YAHAYA AH. 2010. Rheological study of chitosan and its blends: an overview. Maejo Int J Sci Technol 4(02): 210-220.

ERYIGIT T, YILDIRIM B, EKICI K \& ÇIRKA M. 2017. Chemical Composition, Antimicrobial and Antioxidant Properties of Schinus molle L. Essential Oil from Turkey. J Essent Oil Bear Plants 20(2): 570-577.

GIRÃO VCC, NUNES-PINHEIRO DCS, MORAIS SM, SEQUEIRA JL \& GIOSO MA. 2003. A clinical trial of the effect of a mouthrinse prepared with Lippia sidoides Cham essential oil in dogs with mild gingival disease. Prev Vet Med 59(1-2): 95-102.

GUPTA RC, GUPTA DM, LALL R, SRIVASTAVA A \& SINHA A. 2019. Nutraceuticals in Periodontal Health and Diseases in Dogs and Cats. In Nutr in Vet Med, p. 447-466.

HAMMER KA, DRY L, JOHNSON M, MICHALAK EM, CARSON CF \& RILEY TV. 2003. Susceptibility of oral bacteria to Melaleuca alternifolia (tea tree) oil in vitro. Oral Microbiol Immunol 18(6): 389-392.

HUSAIN S, AL-SAMADANI KH, NAJEEB S, ZAFAR MS, KHURSHID Z, ZOHAIBS \& QASIM SB. 2017. Chitosan biomaterials for current and potential dental applications. Materials 10(6): 602.

KAČíROVÁ J, MAĎAR M, ŠTRKOLCOVÁ G, MAĎARI A \& NEMCOVÁ R. 2019. Dental Biofilm as Etiological Agent of Canine Periodontal Disease. In Bacterial Biofilms. Intech Open, p. 1-16.

KATSURA H, TSUKIYAMA RI, SUZUKI A \& KOBAYASHI M. 2001. In vitro antimicrobial activities of bakuchiol against oral microorganisms. Antimicrob Agents Chemother 45(11): 3009-3013.

MACOSSKO CW. 1994. Rheology Principles, Measurements, and Application, New York: VCH Publishers, 549 p.

MARINO M, BERSANI C \& COMI G. 2001. Impedance measurements to study the antimicrobial activity of essential oils from Lamiaceae and Compositae. Int J Food Microbiol 67(3): 187-195.

MARTINS MDR, ARANTES S, CANDEIAS F, TINOCO MT \& CRUZ-MORAIS J. 2014. Antioxidant, antimicrobial and toxicological properties of Schinus molle L. essential oils. J Ethnopharmacol 151: 485-492.

PALOMBO EA. 2011. Traditional medicinal plant extracts and natural products with activity against oral bacteria: potential application in the prevention and treatment of oral diseases. Evid Based Complement Alternat Med, p. 1-15.

PERChYONOK VT. 2018. Copazan Oral Gel: Functional Biomaterial and Periodontal Disease in Veterinary Medicine from Concept to Application in vitro. J Dent Oral Health 4(1): 1-10. ISSN: 2369-4475.

PERIOLI L, PAGANO C, MAZZITELLI S, ROSSI C \& NASTRUZZI C. 2008. Rheological and functional characterization of new anti-inflammatory delivery systems designed for buccal administration. Int J Pharm 356(1-2): 19-28.

PIERI FA, DE CASTRO SOUZA MC, VERMELHO LLR, VERMELHO MLR, PERCIANO PG, VARGAS FS \& MOREIRA MAS. 2016. Use of $\beta$-caryophyllene to combat bacterial dental plaque formation in dogs. BMC Vet Res 12(1): 216.

PIERI FA, SILVA VO, VARGAS FS, VEIGA JUNIOR VF \& MOREIRA MAS. 2014. Antimicrobial activity of Copaifera langsdorffii oil and evaluation of its most bioactive fraction against bacteria of dog's dental plaque. Pak Vet J 34(2): 165-169.

RAMSEIER CA, KINNEY JS, HERR AE, BRAUN T, SUGAI JV, SHELBURNE CA, RAYBURN LA, TRAN HM, SINGH AK \& GIANNOBILE WV. 2009. Identification of Pathogen and Host-Response Markers Correlated With Periodontal Disease. J Periodontol 80(3): 436-446.

RAPP BE. 2017. Microfluidics: modeling, mechanics and mathematics. Elsevier Science, Micro \& Nano. Tech Series, p. 250-253.

SCHOTT H. 1995. Reología. In: Remington Pharmacia. 19. ed. Phennsylvania: Mack Publishing Company, p. 426-455.

SIQUEIRA RCDSS, GUEDES AL, FRATTANI FS, EPIFÂNIO NMM, SOUZA MAA \& CHAVES DSDA. 2020. Chemical profile of Schinus molle L. essential oil and its antihemostatic properties. Nat Vol Essen Oils 7(1): 1-8.

TAKARADA K, KIMUZUKA R, TAKAHASHI N, HONMA K, OKUDA K \& KATO T. 2004. A comparison of the antibacterial efficacies of essential oils against oral pathogens. Oral Microbiol Immunol 19(1): 61-64.

TEELAVATH M \& PATNAIK KR. 2019. Review on buccal adhesive drug delivery system: a promising strategy for poorly soluble drugs. J Drug Deliv Ther 9(3-s): 778-792.

WILLIAMS DW, LEWIS MA, PERCIVAL SL, KURIYAMA T, DA SILVA S \& RIGGIO MP. 2011. Role of biofilms in the oral health of animals. In Biofilms and Veterinary Medicine, p. 129-142.

WRÓBLEWSKA M, SZYMAŃSKA E, SZEKALSKA M \& WINNICKA K. 2020. Different Types of Gel Carriers as Metronidazole Delivery Systems to the Oral Mucosa. Polímeros 12(3): 680 . 


\section{How to cite}

ALVES MCC ET AL. 2020. Chitosan gels for buccal delivery of Schinus molle L. essential oil in dogs: characterization and antimicrobial activity in vitro. An Acad Bras Cienc 92: e20200562. DOI 10.1590/00013765202020200562.

Manuscript received on April 22, 2020

accepted for publication on June 4, 2020

\section{MELINA C.C. ALVES 1}

https://orcid.org/0000-0003-2571-3034

\section{DOUGLAS S.A. CHAVES ${ }^{2}$}

https://orcid.org/0000-0002-0571-9538

\section{BYANCA R. BENEVENUTO}

https://orcid.org/0000-0001-8210-2147

\section{BEATRIZ O. DE FARIAS ${ }^{2}$}

https://orcid.org/0000-0001-7942-0961

SHANA M.O. COELHO 4

https://orcid.org/0000-0003-4165-5735

THAIS P. FERREIRA ${ }^{3}$

https://orcid.org/0000-0001-5804-4522

\section{GERALDO A. PEREIRA ${ }^{1}$}

https://orcid.org/0000-0001-8343-7627

\section{GABRIELA C.M. DOS SANTOS ${ }^{1}$}

https://orcid.org/0000-0001-9995-5357

\section{LEANDRA O. MOREIRA ${ }^{1}$}

https://orcid.org/0000-0001-5417-0476

\section{JULIANA P. DE FREITAS 1}

https://orcid.org/0000-0003-2773-1463

\section{YARA P. CID $^{2}$}

https://orcid.org/0000-0003-0775-0704

1Programa de Pós-Graduação em Ciências Veterinárias, Instituto de Veterinária, Universidade Federal Rural do Rio de Janeiro, BR-465, Km 7, 23897-000 Seropédica, RJ, Brazil

${ }^{2}$ Departamento de Ciências Farmacêuticas, Instituto de Ciências Biológicas e da Saúde, Universidade Federal Rural do Rio de Janeiro, BR-465, Km 7, 23897-000 Seropédica, RJ, Brazil

${ }^{3}$ Programa de Pós-graduação em Química, Instituto de Química, Universidade Federal Rural do Rio de Janeiro, BR-465, Km 7, 23897-000 Seropédica, RJ, Brazil

${ }^{4}$ Departamento de Microbiologia e Imunologia Veterinária, Instituto de Veterinária, Universidade Federal Rural do Rio de Janeiro, BR-465, Km 7, 23897-000 Seropédica, RJ, Brazil
Correspondence to: Yara P. Cid

E-mail:yarapcid@gmail.com

\section{Author contributions}

The development of the study and manuscript was carried out in collaboration with multidisciplinary professionals, aiming to meet all the demands of the project. The development and characterization of the gels were carried out by Melina C.C. Alves, Byanca R. Benevenuto, Thais P. Ferreira, Geraldo A. Pereira, Gabriela C.M dos Santos and Leandra O. Moreira, supervised by Prof. Yara Peluso Cid. The minimum inhibitory concentration test was carried out by Beatriz O. de Farias under the supervision of Prof. Shana M.O. Coelho. The plant material of Schinus molle L., the extraction and elucidation of major components were under the responsibility of Juliana Pereira Freitas under the supervision of Prof. Douglas S. A. Chaves.

(cc) BY 